\title{
APPLICATIONS OF ACTIVATED CARBON IN WASTE WATER TREATMENT AS A LOW COST MEDIA
}

\author{
R.P.K.Dasanayaka \\ Postgraduate Institute of Science, \\ University of Peradeniya, Peradeniya, Sri Lanka
}

\begin{abstract}
Environmental pollution caused by the anthropogenic activities is a global challenge. Pollution due to discharge of untreated wastewater, contributes to it considerably. High expenditures for the treatment technologies can be considered as one of the major reason for improper wastewater discharge. Activated carbon provides an excellent solution for this issue as it can be used as a low cost wastewater treatment adsorbent. This paper review, types of activated carbon, their applications and recovery methods in wastewater treatment. Activated carbon from conventional waste such as agricultural waste, woody waste and non conventional waste such as municipal waste can be used as a low cost media for waste water purifications. Physical and chemical processes are used to improve the adsorption property of the activated carbon. $\mathrm{H}_{3} \mathrm{PO}_{4}, \mathrm{KOH}$ and $\mathrm{ZnCl}_{2}$ are the most frequently used chemicals for the activation process. Granular activated carbon, powdered activated carbon, activated carbon fibers and carbon clothes are the major physical forms of the activated carbon. These physical forms are important to maximize the adsorption process according to the purpose of usage. Activated carbon is used to remove heavy metals, dyes, COD, BOD, organic contaminants and volatile organic compounds in the waste water. Various recovery methods are applied to regenerate activated carbons. Among them, chemical, thermal, and bio regeneration methods are examined. Strengths, weaknesses, opportunities, threats related to use of activated carbon and future research priority areas are also discussed.
\end{abstract}

Keywords-Activated carbon, Adsorbent, Agricultural byproduct, Low cost media, Waste water treatment

\section{INTRODUCTION}

Waste water is one of the common environmental problems thought out the world. Water that contains unwanted substances which adversely affected to the water quality is called as waste water. Waste water is unsuitable for consumption. Waste water generation has been increased in recent decades with industrialization and rapid population growth. Industries, agricultural activities, domestic activities can be considered as the major sources of wastewater. Composition of wastewater is widely depending on the source, where it generates. Microorganisms, organic substances such as food, dead plant and animal materials, human excreta, inorganic substances, chemicals, oil, grease and gasses such as ammonia are the major constituents of waste water. Untreated wastewater with these components may damage to the living beings and the environment.Currently, various biological, chemical and physical treatment methods are available to treat this wastewater before discharge to the environment. With the considerable load of waste water generation in the world it is better to develop innovative easy methods for wastewater treatment.

Adsorption technique is widely used in recently to remove pollutants from both air and water. This technique is mostly effective in removing adrsorbate from wastewater and produce high quality water. This is an economically feasible process. This adsorption process transfers waste chemicals, heavy metals from waste water to the highly porous solid surfaces, such as activated carbon.

Activated carbon(AC) is a good media to remove heavy metal in drinking water treatment process [1]. Activated carbon can be considered as low cost, very effective adsorptive medium. Activated carbon normally called as activated charcoal. coconut shell, lignite are commonly used as activated carbon . Activated carbon is a renewable source because most of the time biomass is used as activated carbon [2].Biomass is becoming popular as a raw material for activated carbon in all around the world. Since it is a renewable source that could be regenerated with low cost [3]. Among the all applications of activated carbon, there are $80 \%$ of $\mathrm{AC}$ is used in waste water and drinking water treatment sector to remove organic and inorganic substance in the water.

There are many research studies related to the utilization of activated carbon. However review articles on applications of the activated carbon in wastewater treatment are limited Therefore, this review paper mainly focuses on the following areas. a)What are the activated carbon b) Preparation of activated carbon. c) Applications of activated carbon in 


\section{International Journal of Engineering Applied Sciences and Technology, 2021 \\ Vol. 5, Issue 11, ISSN No. 2455-2143, Pages 1-8 \\ Published Online March 2021 in IJEAST (http://www.ijeast.com)}

wastewater treatment d) preparation of activated carbon from waste material as a low cost media. e) Regeneration of used activated carbon. f) SWOT analysis on the use of activated carbon for treating wastewater.

\section{WHAT IS ACTIVATED CARBON?}

Activated carbon (AC) is produced by thermal decomposition, partial or full combustion process of carbonaceous materials. AC is a highly porous material with large surface area Therefore AC has high adsorption capacities; Activated carbon can adsorb volatile organic compounds such as benzene, ethanol formaldehyde, n-hexane and toluene. Activated carbon has a combination of graphite like micro crystalline structure and amorphous chemical structure. Randomly oriented slit- shaped channels of micro crystalline inter layers have $0.34-0.35 \mathrm{~mm}$ spaces [4]. Those spaces are larger than the graphite spaces $(0.335 \mathrm{~mm})$. The chemical composition of the activated carbon contains carbon, oxygen, nitrogen and hydrogen atoms. These hydrogen, oxygen and nitrogen atoms are bonded at the edges and corners of the carbon aromatic sites. Porosity of the AC depends on the carbonization process, conditions and types of activating agents [4]. Porosity is one of the important characteristic of AC materials. The carbon content of the material, activation potential, cost and density are the factors need to be considered in producing activate carbon.

\section{PREPARATION OF ACTIVATED CARBON}

\section{I.I. PHYSICAL ACTIVATION PROCESS}

According to the porous texture of activated carbons can be classified according to the pore width as micro pores $(<2$ $\mathrm{mm})$, meso pores $(2-50 \mathrm{~mm})$ and macro pores $(>450 \mathrm{~mm})$ [4]. Physical and chemical treatments are used to improve the adsorption ability and pore spaces in the activated carbon. Physical activation has two stages. Thermal carbonization occurs at the first stage of the physical activation process. At the first stage, carbonization process happens below $800^{\circ} \mathrm{C}$ temperature, in the absence of oxygen. Devolatilization takes place to produce char in carbonization process [5]. At the second stage, char is activated using steam, or $\mathrm{CO}_{2}$. Carbonization process burns off non - carbon and produces char with high carbon content. Compounds pyrolizes at high temperatures, ranging from $600{ }^{0} \mathrm{C}$ to $1100{ }^{\circ} \mathrm{C}$ [6]. Carbon is oxidized by oxygen to the carbon dioxide. Air should be kept on very controlled during the activating process. At high temperature, char reacts with this oxidation agent and removes carbon atoms by developing large internal surface area and forms porous structure. At the temperature 800- $1000{ }^{0} \mathrm{C}$ stream and carbon dioxide act as oxidizing agents as following [7] :-

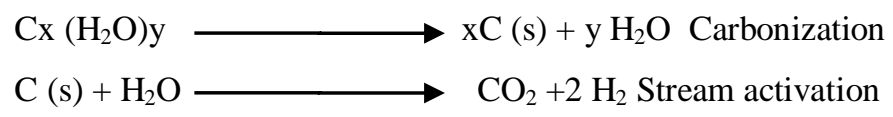

Porosity depends on the conditions such as temperature, mass ratio of carbon to oxygen and flow rate. If necessary, additional treatment processes process are applied [5].The method of activation depends on density of the material and physical characters (Granular or Powered) of the material.

\section{I.II. CHEMICAL ACTIVATION OF CARBON}

Chemical activation is another activation process, that used to improve pore spaces in the activated carbon. It is a single stage process used to prepare activated carbon. Phosperic acid $\left(\mathrm{H}_{3} \mathrm{PO}_{2}\right)$ Zinc chloride $\left(\mathrm{ZnCl}_{2}\right)$, Potassium carbonate $\left(\mathrm{K}_{2} \mathrm{CO}_{3}\right)$, Potassium hydroxide $(\mathrm{KOH})$ Sulphuric acid $\left(\mathrm{H}_{2} \mathrm{SO}_{4}\right)$ are some chemical agents that can be used to improve the porosity of the activated carbon [8]. Activated carbon and chemical mixture, should heat around $750{ }^{\circ} \mathrm{C}$. Chemical activating agents are more favorable than physical activation agents due to high yield and low temperature (Low energy) requirements. The economic value of the activated carbon as an adsorbent depends on its capacity, stability and reusable ability for adsorption process. The adsorption capacity of the activated carbon mostly depends on porosity of the material. Carbon surfaces with oxygen functional groups are classified into three groups such as acidic, basic and neutral groups.

\section{II.CLASSIFICATIONS OF ACTIVATED CARBON}

\section{II.I. GRANULAR ACTIVATED CARBON}

Granular activated carbon performs as fixed bed columns. Hard materials such as wood, coal, lignite, peat, and coconut shells are used to prepare granular activated carbons. Normally particles size is larger than $0.177 \mathrm{~mm}$. It is commonly used as column filters to remove gas or liquid. Granular activated carbon can adsorb considerable contaminants in water due to large surface area. Granular activated carbon can be regenerated after use through thermal degradation process. Pore distribution of granular activated carbon is shown in Figure:1[4].

\section{II.II. Powdered activated carbon}

Diameter of Powered AC is lower than $0.2 \mathrm{~mm}$. It is typically ranges from 5- $50 \mu \mathrm{m}$. Powdered activated carbon cannot be regenerated or recovered after sorption of contaminants. Powdered AC is applied to municipal waste water treatment, and food industry for odor control [4]. Powdered AC are shown in first image of the Figure:2 [4]. Wood saw dust is used as powdered activated carbon. Powered activated carbons are very effective than granular activated carbon, due to small particle size. Powdered activated carbon sedimentation done aided with coagulants. 
About $50 \%$ of the total production of activated carbons are produced as powdered activated carbons [5].



Figure 1: Pore size distribution of granular activated carbon [4]

\section{II.III. ACTIVATED CARBON FIBERS}

AC fibers and activated carbon fabrics were initially developed in 1970, used as precursor's phenol or viscose rayon. Activated carbon fiber is heat treated in an oxidizing atmosphere to activate. Homogeneous polymeric raw materials are used to prepare activated carbon fibers. Fiber shape is improved the contact efficiencies between the media and adsorbent. Activated carbon fabrics can be prepared as fabric or felt. Synthetic cloths such as Rayon, Kevlar can be used to manufacture activated carbon fabrics [9].
Powdered Activated Carbon

(PAC)
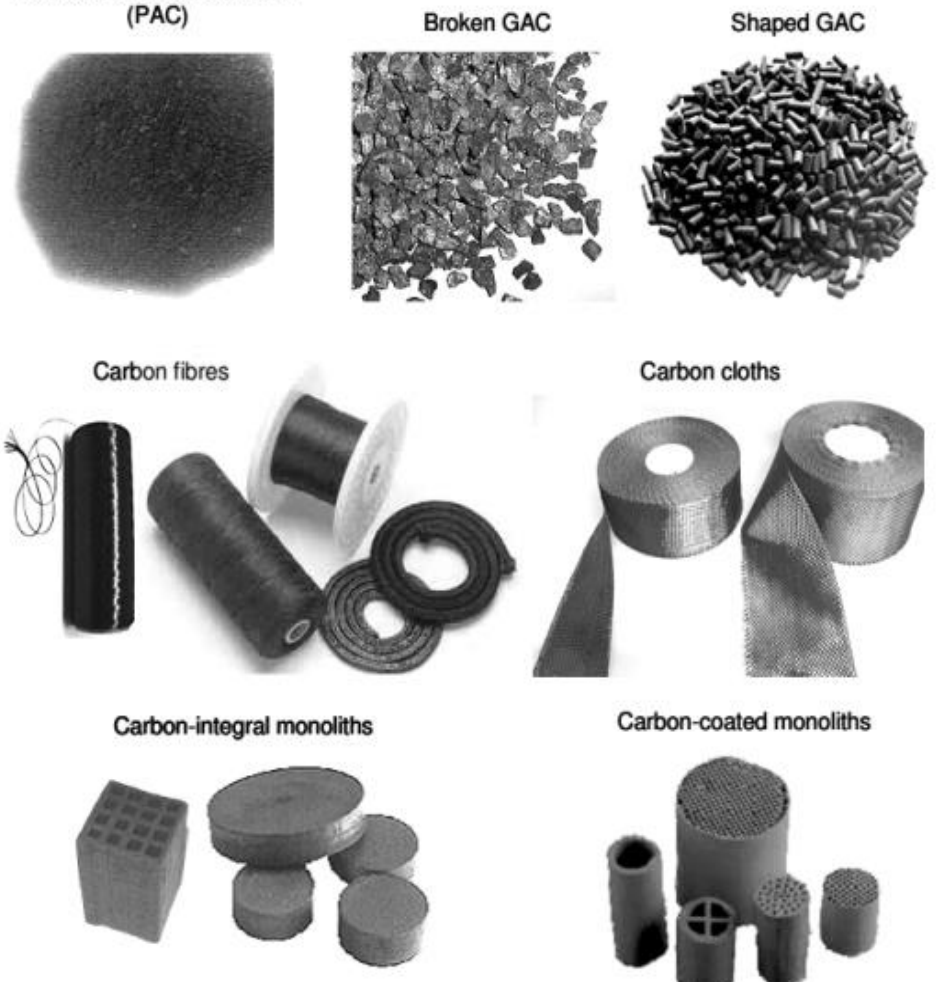

Carbon-coated monoliths

Carbon membrane supported on stainless steel

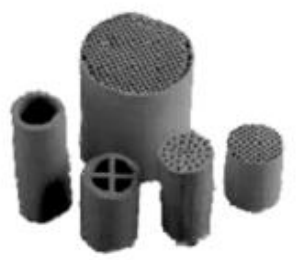

Figure 2: Different forms of activated carbon [4]

\section{PREPARATION OF ACTIVATED CARBON FROM WASTE MATERIALS AS LOW COST MEDIA}

Various raw materials can be used to produce activated carbon. Conventional waste materials such as Agricultural waste materials, woody waste materials, and non conventional waste such as municipal waste materials and industrial waste materials are major waste materials that can be used to prepare activated carbon. Waste based activated carbon has many advantages, because they have economically and environmentally friendly nature. Waste can be used as low cost media for produce activated carbon. There are numerous studies are carrying out regarding the use of waste as activated carbon [6]. 


\section{International Journal of Engineering Applied Sciences and Technology, 2021 \\ Vol. 5, Issue 11, ISSN No. 2455-2143, Pages 1-8 \\ Published Online March 2021 in IJEAST (http://www.ijeast.com)}

Table 1: Different types of agricultural waste used to remove different contaminants in waste water.

\begin{tabular}{|c|c|c|c|}
\hline $\begin{array}{l}\text { Type } \\
\text { of } \\
\text { agricu } \\
\text { ltural } \\
\text { waste }\end{array}$ & $\begin{array}{c}\text { Conta } \\
\text { minant } \\
\text { remove } \\
\quad \text { d }\end{array}$ & Highlights & Reference \\
\hline $\begin{array}{l}\text { Cocon } \\
\text { ut } \\
\text { shell }\end{array}$ & $\begin{array}{l}\text { Heavy } \\
\text { metal }\end{array}$ & $\begin{array}{l}\text { Coconut shell carbon can be } \\
\text { used as low cost effective } \\
\text { media to remove } \mathrm{Zn} \mathrm{in} \\
\text { Aqueous solution, Removal } \\
\text { efficiency is depend on pH, } \\
\text { concentration of adsorbent, } \\
\text { agitation times, and particle } \\
\text { size }\end{array}$ & [10] \\
\hline $\begin{array}{l}\text { Rice } \\
\text { husk }\end{array}$ & $\begin{array}{l}\text { Crude } \\
\text { oil, } \\
\text { Diesel } \\
\text { fuel }\end{array}$ & $\begin{array}{l}\text { Black rice husk ash activated } \\
\text { carbon is an effective } \\
\text { adsorbent for spill oil, grease } \\
\text { purification of water. }\end{array}$ & [11] \\
\hline $\begin{array}{l}\text { Rice } \\
\text { husk }\end{array}$ & NOM & $\begin{array}{l}\text { Activated carbon with meso } \\
\text { pores }(2-50 \mathrm{~mm} \text { width) and } \\
\text { micro pores }(1-2 \mathrm{~mm} \text { width) } \\
\text { are well adsorbing NOM in } \\
\text { water. Rice husks are low } \\
\text { cost adsorbents when } \\
\text { compared with other } \\
\text { commercial AC. }\end{array}$ & [12] \\
\hline $\begin{array}{l}\text { Coir } \\
\text { pith }\end{array}$ & $\begin{array}{l}\text { Dye, } \\
\text { COD }\end{array}$ & $\begin{array}{l}\text { Coir pith carbon } \\
\text { significantly reduces dye } \\
\text { color and COD in textile } \\
\text { industry waste water. } \\
\text { Adsorption efficiency } \\
\text { increases with column bed } \\
\text { depth and decreases with } \\
\text { flow rate of water. }\end{array}$ & [13] \\
\hline $\begin{array}{l}\text { Sugar } \\
\text { cane } \\
\text { bagass } \\
\text { e }\end{array}$ & $\begin{array}{l}\text { Heavy } \\
\text { metal }\end{array}$ & $\begin{array}{l}\text { Activated carbons prepared } \\
\text { through chemically } \\
\text { activation using Zinc } \\
\text { chloride have a high } \\
\text { adsorption capacities for } \\
\text { removing Cr (VI) irons. }\end{array}$ & [14] \\
\hline $\begin{array}{l}\text { Olive } \\
\text { cake }\end{array}$ & $\begin{array}{l}\text { Herbici } \\
\text { des }\end{array}$ & $\begin{array}{l}\text { Activated carbon with larger } \\
\text { macro-pores and micro- } \\
\text { pores has better potential for } \\
\text { herbicide absorption. }\end{array}$ & [15] \\
\hline $\begin{array}{l}\text { Pecan } \\
\text { shell }\end{array}$ & VOC & $\begin{array}{l}\text { Very effective adsorption for } \\
\text { the benzene. }\end{array}$ & [16] \\
\hline
\end{tabular}

III.II. OTHER WASTE MATERIALS (MUNICIPAL AND INDUSTRIAL WASTES)

In the modern world, solid waste is rapidly generated due to the industrial and domestic activities. Plastic, tires, PET bottles, fabrics are major municipal solid waste generated in today. They are disposed to the landfill site or incinerated. Waste management is a global problem. This waste is a good source for activated carbon. Considerable number of studies has been carried out to use of municipal waste as activated carbon for the wastewater treatment [17]. Raw materials such as polyethylene and plastic are normally used to prepare activated carbon fibers. Organic materials, heavy metals such as mercury, nickel and copper can be removed using these activate carbon. These activated carbons are economically viable and have a good adsorption mechanism. Related studies on waste materials are presented in Table: 02

Table 2: Different types of municipal waste for removal of remove contaminants in water

\begin{tabular}{|l|l|l|}
\hline Waste material & $\begin{array}{l}\text { Contaminant } \\
\text { removed }\end{array}$ & Reference \\
\hline PET bottles & $\begin{array}{l}\text { Phenols, Organic } \\
\text { compounds }\end{array}$ & {$[19]$} \\
\hline Waste tires & $\mathrm{Cr}(11)$ & {$[17]$} \\
\hline $\begin{array}{l}\text { Denim fabric } \\
\text { waste }\end{array}$ & Textile dye & {$[18]$} \\
\hline Coal tar pitch & Organic compounds & {$[13]$} \\
\hline
\end{tabular}

\section{APPLiCATIONS OF ACTIVATED CARBON IN WASTE WATER TREATMENT}

Waste water generated due to industrial, agricultural and domestic activities may contain toxic chemicals, heavy metals, organic pollutants and inorganic substances. Activated carbon is majorly used in aqueous phase treatments. Activated carbon is used to treat waste water, contaminated ground water and drinking water. In the wastewater treatment systems adsorption technology of activated carbon is normally used in the primary treatment, other water purification process, or finally in the advanced treatment process [20].

Molecular size, solubility of the adsorbate mainly affects the adsorption process of the activated carbon. The adsorption process of activated carbon is a result of interactions between the activated carbon surface and adsorbate [21]. Both electrolyte and non electrostatic interactions occur in the adsorption process. Electrolyte adsorbate interactions occur with the electrical charge density of the activated carbon, chemical characteristic of the adsorbate, and ionic strength of 


\section{International Journal of Engineering Applied Sciences and Technology, 2021 \\ Vol. 5, Issue 11, ISSN No. 2455-2143, Pages 1-8 \\ Published Online March 2021 in IJEAST (http://www.ijeast.com)}

the solution. Hydrogen bonds, Vander Waals forces and hydrophobic interactions are non electrostatic interactions.

\section{IV.I. HEAVY METAL AND ORGANIC SUBSTANCES ADSORPTION IN WASTE WATER}

Waste water with heavy metals are discharged by the Industrial activities such as vehicle manufacturing, paint industries, mining industries and agricultural activities such as fertilizer manufacturing industries. According to the world health organization Chromium, Copper, Cadmium, Lead, Mercury and Nickel are considered as most toxic heavy metals. Many studies showed that adsorption process of activated carbon is a more economically and technically feasible method to remove heavy metals in waste water [22]. Different studies on the heavy metal adsorption from wastewater are shown in Table 03. Metallic ions chemical structure, $\mathrm{pH}$ of the solution, surface charges, porosity of surface area and composition are some of the factors that control the metal iron adsorption.

Table 3: Removal of different heavy metals using different low cost activated carbon

Industrial waste, agricultural fertilizers, pesticides are the major sources of organic pollutants that added to the water bodies.

\begin{tabular}{|c|c|c|c|}
\hline $\begin{array}{c}\text { Heavy } \\
\text { metal }\end{array}$ & $\begin{array}{c}\text { Type of } \\
\text { activated } \\
\text { carbon }\end{array}$ & Remarks & References \\
\hline $\begin{array}{l}\text { Cd(ii), } \\
\text { Zn( ii) }\end{array}$ & $\begin{array}{c}\text { Sugar } \\
\text { bagasse }\end{array}$ & $\begin{array}{l}\text { The adsorption } \\
\text { kinetics of adsorption } \\
\text { of those ions depend } \\
\text { on the concentration } \\
\text { and the characteristics } \\
\text { of the adsorbent. }\end{array}$ & [23] \\
\hline $\begin{array}{l}\mathrm{Pb}(\mathrm{II}) \\
\mathrm{Hg}(\mathrm{II}) \\
\mathrm{Cu}(\mathrm{II})\end{array}$ & $\begin{array}{l}\text { Coconut } \\
\text { buttons }\end{array}$ & $\begin{array}{l}\text { Adsorption capacities } \\
\text { decrease as } \mathrm{Pb}(\mathrm{II}) \\
>\mathrm{Hg}(\mathrm{II})>\mathrm{Cu}(\mathrm{II}) \\
\text { Metal ions are } \\
\text { removed through } \\
\text { batch adsorption } \\
\text { process. Good } \\
\text { adsorption potential } \\
\text { for } \mathrm{Hg} \text { (II) at } \mathrm{PH} 7.0 \\
\text { and } \mathrm{Pb} \text { (II) and } \mathrm{Cu} \text { (II) } \\
\text { at } \mathrm{pH} 6.0 .\end{array}$ & [24] \\
\hline $\mathrm{Cu}$ (II) & $\begin{array}{l}\text { Granular } \\
\text { activate } \\
\text { carbon }\end{array}$ & $\begin{array}{l}\text { Present of humic acids } \\
\text { increases the copper, } \\
\text { iron adsorption. }\end{array}$ & [25] \\
\hline $\mathrm{Li}$ & $\begin{array}{l}\text { Electroch } \\
\text { emical } \\
\text { polarized } \\
\text { activated } \\
\text { carbon }\end{array}$ & $\begin{array}{l}\text { Adsorption properties } \\
\text { of AC depend on the } \\
\text { physiochemical nature } \\
\text { of surface and texture } \\
\text { such as pore volume, } \\
\text { pore distribution. }\end{array}$ & [25] \\
\hline
\end{tabular}

Waste water from Food and beverage industries, rubber industries contain high amount of organic substances. Applications of biological treatment process to remove organic contaminants from aqueous solutions are very ineffective and time consumed. Activated carbons are more effective to remove synthetic and naturally occurring organic substances in water. Pore sizes distribution, mineral matter content, and surface chemistry of AC is important to adsorb organic compounds to the AC. Adsorption capacities of organic substances to the AC depend on the size of the Organic substances. Small molecules such as phenol compounds can access to the micro pores, organic substances can attach to the meso pores, and bacteria can access to the macro pores of activated carbon. Adsorption mechanism of AC is driven by an electrostatic force and tail groups of surfactant [26].

\section{REGENERATION OF USED ACTIVATE CARBON}

When activated carbon is used to remove adsorbate from liquid, stream or gas carbon become saturated with the adsorbent. When the adsorption capacity of activated carbon decreases, it is unacceptable to further adsorb pollutants. When activated carbons exceed its adsorption capacity, there are two options. It can be disposed or it can be regenerated for reutilization. Regeneration of activated carbon is better for the reduction of waste and the cost. In some occasions regeneration cost may be higher than the production cost or regenerated activated carbon occupy with low adsorption capacity than the original activated carbon [5].

After completion of several regeneration cycle adsorption capacity of activated carbon decreases. Hereafter activated carbon cannot be regenerated any more. It is difficultly to regenerate powdered activated carbon. Granular activated carbons can be easily regenerated. Granular activated carbon has a higher demand than powdered activated carbon. Activated carbon can be regenerated at the site or by contacting the manufacturer. There are several technologies used to regenerate activated carbon [5].

\section{V.I. CHEMICAL REGENERATION}

Relevant chemicals such as sodium hydroxide, Sodium bicarbonate are used as regenerate agents. These chemicals react with adsorbate. As an example, sodium hydroxide reacts with the phenol and form sodium phenol, substances dissolved in water. Acid can be used as regeneration agents to remove heavy metals from activated carbon. Chemical agents affect to porosity and reduce the regeneration capacity of the activated carbon [5].

\section{V.II. THERMAL REGENERATION}

Thermal generation has been a most frequently applied method to regenerate exhausted activated carbon. Activated carbon is heated at the temperature between $800-1274 \mathrm{~K}$ inside the different types of furnace. Different research studies were 


\section{International Journal of Engineering Applied Sciences and Technology, 2021 \\ Vol. 5, Issue 11, ISSN No. 2455-2143, Pages 1-8 \\ Published Online March 2021 in IJEAST (http://www.ijeast.com)}

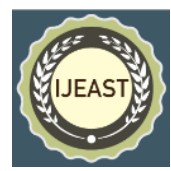

carried out at different temperatures to regenerate activated carbon. Stream or heated nitrogen is used to remove organic contaminants and regenerate exhausted activated carbon. Convent heat treatment methods, rotary kiln, fluidized bed furnace and microwave furnace is used in the thermal heat treatment process. Microwave furnaces are more efficient and less time consumed than conventional finances. Thermal regeneration is a High energy consuming process [27].

\section{V.III. Bio regeneration of activated carbon}

Recovery of adsorptive capacity in activated carbon using aerobic, anaerobic microorganisms for further adsorption is called as bio regeneration. Microorganisms digest the compounds and transform them into the nontoxic substances. Bio regeneration process improves is improved the self life of activated carbons. Microbes use organic substrates to generate energy, break down the substrate to simple molecules or irons, such as $\mathrm{CO}_{2}, \mathrm{CH}_{4}$ and $\mathrm{Cl}^{-}$. Bio regeneration occurs due to the concentration gradient between the activated carbon and liquid bulk. Bio regeneration occurs only in desorption materials. Comparing with thermal regenerations this method is consumed low temperature and low energy. But $\mathrm{pH}$, temperature and concentrations of the solution need to be controlled control to keep favorable conditions for microorganisms.

\section{V.IV. Steam regeneration}

Stream generation is commonly used for regeneration of activated carbon with low boiling point materials. This process operates at low temperatures. When activated carbon is saturated, a stream flows through the activated carbon bed. Due to the heat of stream desorbs the adsorbate from the activated carbon. Hot Nitrogen or heated air can be used instead of the stream [28].

\section{SWOT ANALYSIS OF ACTIVATED CARBON IN WASTEWATER TREATMENT SECTOR}

\section{STRENGTH}

Reuse of agricultural byproducts and municipal wastes for activated carbon is offered a sustainable end point solution for solid waste disposal. This will be a considerable alternative for the waste disposal. Wastewater generation is increasing day by day and the demand for clean water is also increased due to the rapid population growth in the world. Therefore, utilization of agricultural byproducts and waste materials as low cost materials for the AC production is a huge strength. With the availability of local, low cost resources people will apply activated carbon for aqueous phase and gaseous phase treatment. Activated carbon is a low cost inert substance, so interactions between carrier and active phase are very limited, that will be strength for wide applications of activated carbon.
Large internal surface area of the AC is carried out more compounds than other oxide carriers. Activated carbons can be used for high temperatures due to the stability of the activated carbon inert atmosphere. When compared with other carriers activated carbon is relatively cheap. Activated carbon has a better electrical conductivity and shows a faster heat transport than other oxide carriers.

\section{WEAKNESS}

Some activated carbon materials such as coal and lignite are expensive non renewable resources. Materials such as coconut shells, rice husks are not readily available at everywhere. Agricultural waste may have lot of impurities, so need to bear additional costs and pretreatment process to remove those impurities. Some materials have extra processes such as binding and pelletization (Lima \& Marshall, 2005). Powdered AC cannot be recovered and it is also difficult to extract from water treatment plants. Chemical agents that are used to regenerate AC are very expensive and this chemical agents affects are affected porosity and reduce the regeneration capacity of the activated carbon [5]. AC has a short services life, and need to be replaced when bonding sites of the activated carbon is filled with contaminants. Some AC could remove specific contaminants, so using one type of AC cannot remove all contaminants.

\section{OPPORTUNITIES}

With the current situation of waste generation and waste management it is essential to identify opportunities for manufacturing activated carbon using locally available materials. Also need a proper assessment of possible risks and identify feasibility of the applications of those materials as activated carbon. As an income generation source, waste can convert into the activated carbon. Activated carbon can be applied to the wastewater treatment plants with a small process modification. Industries can be encouraged by giving opportunities to manufacture activated carbon from locally available materials. Most of the above findings are limited to the laboratory experiment or/ researches, therefore there is a great opportunity to identify practicability of the above findings for wastewater treatment.

\section{THREATS}

Lack of knowledge and awareness regarding the optimum activation conditions such as temperatures, times, environmental conditions regarding the activation time is more problematic. Final disposal of end used activated carbon with the pollutants will be a great problem. The type of AC applied is changing from one water treatment plant to another. Waste and agricultural byproduct used for the AC are not always safe. Quality of the Agricultural byproducts will be changed with the seasonal variations. 


\section{International Journal of Engineering Applied Sciences and Technology, 2021 \\ Vol. 5, Issue 11, ISSN No. 2455-2143, Pages 1-8 \\ Published Online March 2021 in IJEAST (http://www.ijeast.com)}

\section{CONCLUSION}

Depletion of clean water is becoming a critical issue in these days. The presence of contaminants such as heavy metals, organic matters, and volatile organic compounds due to the anthropogenic activities, affects to human health. As a good adsorbent, activated carbon is becoming more popular in many applications, including water treatment. It can be used for process modification in the waste water treatment plants. There are vast varieties of natural, low cost materials that can be selected as raw materials for activated carbon. But their activations conditions differ from each other. Optimum conditions should be identified to activate that AC. Most of the time specific contaminants are removed by specified activated carbons. In aqueous phase treatment, activated carbon can remove heavy metals, volatile organic compounds, and organic matter in the water. Conventional waste such as agricultural byproducts, woody materials and non conventional waste such as municipal waste can be used as activated carbon to purify gaseous and aqueous phase pollutants. Further studies should be conducted to applications of new materials such as banana trunk fibers, fabric waste as activated carbon. These research studies should expand into practical applications. Use of activated carbon in waste water treatment in automobile services, Rubber factories, hairdressing saloons and odor control are still not properly assessed. Research studies under the oil removal using $\mathrm{AC}$ should be conducted. Economic feasibility of different activated carbon recovery methods and activation methods should be properly evaluated.

\section{REFERENCE}

[1] Babel, S., and Kurniawan, T. A. (2003). Low-cost adsorbents for heavy metals uptake from contaminated water : a review,(pp 219-243).

[2] Menya, E., Olupot, P. W., Storz, H., Lubwama, M., and Kiros, Y. (2017). SC. Chemical Engineering Research and Design

[3] Rashwan, W. E., Girgis, B. S., and Chemistry, S. (2003). Adsorption Capacities of Activated Carbons Derived from Rice Straw and Water Hyacinth in the Removal of Organic Pollutants from Water, (pp.181-194).

[4] Moona, N. (2017). Partial renewal of granular activated carbon filters for improved drinking water treatment Department of Architecture and Civil Engineering.

[5] Ed, B., Men, J. A., and Mart, I. (2006). Types of carbon adsorbents and their production (Vol. 2006).

[6] Dias, J. M., Alvim-ferraz, M. C. M., Almeida, M. F., and Sa, M. (2007). Waste materials for activated carbon preparation and its use in aqueous-phase treatment 85 , (pp.833-846).
[7] Ansari, R. (2009). Activated Charcoal: Preparation, characterization and Applications : A review article, 1(4), (pg.859-864).

[8] Diao, Y., Walawender, W. P., and Fan, L. T. (2002). Activated carbons prepared from phosphoric acid activation of grain sorghum. Bioresource Technology, 81(1), (pp.45-52).

[9] Yu, J. J., and Chou, S. Y. (2000). Contaminated site remedial investigation and feasibility removal of chlorinated volatile organic compounds from groundwater by activated carbon fiber adsorption. Chemosphere, 41(3), (pp.371-378).

[10] Amuda, O. S., Giwa, A. A., and Bello, I. A. (2007). Removal of heavy metal from industrial wastewater using modified activated coconut shell carbon. Biochemical Engineering Journal, 36(2),(pp.174-181).

[11] Vlaev, L., Petkov, P., Dimitrov, A., and Genieva, S. (2011). Cleanup of water polluted with crude oil or diesel fuel using rice husks ash. Journal of the Taiwan Institute of Chemical Engineers, 42(6),(pp.957-964).

[12] Menya, E., Olupot, P. W., Storz, H., Lubwama, M., and Kiros, Y. (2017). SC. Chemical Engineering Research and Design.

[13] Santhy, K., and Selvapathy, P. (2006). Removal of reactive dyes from wastewater by adsorption on coir pith activated carbon. Bioresource technology, 97(11), (pp.1329-1336).

[14] Cronje, K. J., Chetty, K., Carsky, M., Sahu, J. N., and Meikap, B. C. (2011). Optimization of chromium (VI) sorption potential using developed activated carbon from sugarcane bagasse with chemical activation by zinc chloride. Desalination, 275(1-3),(pp.276-284)

[15] Bac-aoui, A., Yaacoubi, A., Dahbi, A., Bennouna, C., Phan Tan Luu, R.,Maldonado-Hodar, F.J., Rivera-Utrilla, J., Moreno-Castilla, C., 2001.Optimization of conditions for the preparation of activated carbon from olive-waste cakes. Carbon (pp.425-432).

[16] Zhang, T., Walawender, W. P., Fan, L. T., Fan, M., Daugaard, D., and Brown, R. C. (2004). Preparation of activated carbon from forest and agricultural residues through $\mathrm{CO} 2$ activation. Chemical Engineering Journal,(pp. 53-59).

[17] Gupta, V. K., Ali, I., Saleh, T. A., Siddiqui, M. N., \& Agarwal, S. (2013). Chromium removal from water by activated carbon developed from waste rubber tires. Environmental Science and Pollution Research, 20(3), (pp.1261-1268)

[18] Silva, T. L., Cazetta, A. L., Souza, P. S., Zhang, T., Asefa, T., and Almeida, V. C. (2018). Mesoporous activated carbon fibers synthesized from denim fabric waste: efficient adsorbents for removal of textile dye from aqueous solutions. Journal of Cleaner Production, (pp.482-490). 
[19] Laszlo, K., Tombacz, E., and Josepovits, K. (2003). Surface characterization of a polyacrylonitrile based activated carbon and the effect of $\mathrm{pH}$ on its adsorption from aqueous phenol and 2,3,4-trichlorophenol solution. Periodica Polytechnica Chemical Engineering, 47(2), (pp.105-116).

[20] Thines, R. K., Mubarak, N. M., Nizamuddin, S., Sahu, J. N., Abdullah, E. C., and Ganesan, P. (2017). Application potential of carbon nanomaterials in water and wastewater treatment. Journal of the Taiwan Institute of Chemical Engineers,(pp.116-133).

[21] Rivera-Utrilla, J., Prados-Joya, G., Sánchez-Polo, M., Ferro-García, M. A., and Bautista-Toledo, I. (2009). Removal of nitroimidazole antibiotics from aqueous solution by adsorption/bioadsorption on activated carbon. Journal of Hazardous Materials, 170(1),(pp.298-305).

[22] Di Natale, F., Lancia, A., Molino, A., \&Musmarra, D. (2007). Removal of chromium ions form aqueous solutions by adsorption on activated carbon and char. Journal of Hazardous Materials, 145(3),(pp.381-390)

[23] Mohan, D., and Singh, K. P. (2002). Single- and multicomponent adsorption of cadmium and zinc using activated carbon derived from bagasse - An agricultural waste. Water Research, 36(9),(pp.2304-2318).

[24] Anirudhan, T. S., and Sreekumari, S. S. (2011). Adsorptive removal of heavy metal ions from industrial effluents using activated carbon derived from waste coconut buttons. Journal of Environmental Sciences, 23(12), (pp.1989-1998)

[25] Di Natale, F., Lancia, A., Molino, A., and Musmarra, D. (2007). Removal of chromium ions form aqueous solutions by adsorption on activated carbon and char. Journal of Hazardous Materials, 145(3),(pp.381-390)

[26] Al-Ghouti, M. A., and Al-Degs, Y. S. (2011). New adsorbents based on microemulsion modified diatomite and activated carbon for removing organic and inorganic pollutants from waste lubricants. Chemical engineering journal, 173(1), (pp.115-128).

[27] Kane, S. N., Mishra, A., and Dutta, A. K. (2016). Preface: International Conference on Recent Trends in Physics (ICRTP 2016). Journal of Physics: Conference Series.

[28] Amuda, O. S., Giwa, A. A., and Bello, I. A. (2007). Removal of heavy metal from industrial wastewater using modified activated coconut shell carbon. Biochemical Engineering Journal, 36(2),(pp.174-181).

[29] Lima, I., \& Marshall, W. E. (2005). Utilization of turkey manure as granular activated carbon: Physical, chemical and adsorptive properties. Waste Management, 25(7), (pp.726-732). 